\title{
Carta Sobre una Reseña de Sharon Magnarelli
}

Buenos Aires, 24 de noviembre de 1977

Sr. Alfredo Roggiano

Director de la Revista Iberoamericana

Universidad de Pittsburgh

Pittsburgh, Pennsylvania

Distinguido colega:

Al recibir el No 96-97 de la Revista Iberoamericana y leer con el interés de siempre su contenido, quedé sorprendida frente a la reseña que se publica en las páginas 634-35 acerca de mi libro El discurso indirecto libre en la novela argentina.

Dicha reseña adolece de muchos y graves errores. Entre ellos señalo los más serios:

1) Se tergiversa la definición del discurso indirecto libre (DIL) al citar la página 12 y transcribir como DIL lo que expongo precisamente acerca del discurso indirecto (DI). Se confunde mi apreciación del discurso directo y del discurso indirecto. Mi definición del DIL se halla en la página 47 de mi libro y es la siguiente: "El discurso indirecto libre es una forma caracterizada estructuralmente por generarse a partir del discurso indirecto (DI) con la omisión de verbos introductores y nexos. Esta transformación (según la terminología de Chomsky) tiene gran importancia en el campo estilǐstico porque abre nuevos caminos a la expresión."

2) En ningún momento se ha pretendido agotar la bibliografǐa existente relativa a cada autor, porque el objeto de la investigación es rastrear la presencia de un recurso estilístico. Además, mal se puede 
imputar la omisión de críticas aparecidas con posterioridad a mi disertación (1968). En cuanto al desdén con que se contempla la bibliografĩa que utilizo, deseo puntualizar que esos autores son nombres de gran prestigio y que en algunos casos me remito a la Bibliografía Argentina de Artes y Letras, Fondo Nacional de las Artes, dirigida por Augusto Raúl Cortázar, material que aprovechan inteligentemente en USA. (Véanse entre otras pp. 101 y $211 \mathrm{de} \mathrm{mi}$ libro)

3) Entre las suposiciones que la comentarista declara "haber podido entender" se encuentra la siguiente: "No hay ejemplos de DIL antes de mediados del siglo XIX". Debo aclarar que reiteradas veces he aludido en el texto a la antigüedad de esta forma, atestiguada por todos los estudiosos y apoyándome particularmente en Friedrich Todemann para el DIL en español. En cambio al referirme al DIL en la novela argentina hago notar la ausencia de ese estilema hasta la mitad del siglo XIX.

4) No es exacto que yo declare "estudio lingüisstico" a mi investigación. Parto del hecho linguïstico para llegar al estilistico y lo refirmo a lo largo del trabajo, particularmente en los estudios dedicados a los escritores argentinos del siglo XX: Larreta, Güiraldes, Mallea, Sábato, Cortázar y Borges y en el capitulo XII al explicar el particular método seguido para el estudio estadístico y la frecuencia de uso del recurso estilistico (p. 217 y ss).

5) No es verdad que yo examino numerosas novelas, opinión que la lleva a concluir que "la cantidad que se pretende analizar no admite un estudio profundo de ninguna". Aunque hago observaciones sobre el DIL en veinte autores, el examen detenido y el estudio estadístico se realiza sobre siete obras.

6) Yo no cito en mi bibliografía ni a Benveniste ni a Derrida como falsamente se me acusa, con el agregado de que los cito y no me sirvo de ellos en mi estudio: ". . . no muestra cómo estas teorías modifican o inspiran las suyas" (p. 635, Rev. Iberoamericana, No 96-97). En ningún momento me ocupo de estos autores y causa asombro tan malévola acusación.

En cuanto al nombre de R. Barthes en el cuadro de la p. 37 correspondiente al capitulo "El DIL y las teorias modernas" - y por lo tanto en la bibliografía- se debe a la inclusión de un apéndice que por razones de la Editorial apareció posteriormente. En el mismo apéndice se hallan P. Guiraud, J. Starobinski, D. Cohn y los Retóricos de Lieja, citados igualmente en el cuadro antedicho. 
Es lamentable que en una reseña se trasluzca tanta arbitrariedad e ignorancia pero más lamentable aún es que la Srta. Sharon Magnarelli confunda un trabajo estilístico con un trabajo lingüistico.

Saludo a Ud. con alta estima,

PETRONA DOMINGUEZ DE RODRIGUEZ PASQUES Universidad de Buenos Aires 
